\title{
Raquel Padilla Ramos, vocera de los sueños y luchas yaquis ${ }^{1}$ \\ (Hermosillo, 19/9/1967 - Ures, 7/11/2019)
}

\section{Algunas anécdotas}

Conocí a Raquel en mayo de 1991. ¡Ambos coincidimos en la redacción del periódico Por Esto! en Mérida. Yo entregaba un artículo y ella, si recuerdo bien, apoyando como redactora. El periodista e historiador Hernán Menéndez ${ }^{2}$ nos presentó en los pasillos y luego en su oficina entablamos por primera vez, como en otras ocasiones, largas y amenas charlas sobre historia, beisbol, política, pueblos originarios, religión y más. Raquel conocía a detalle la historia de los Naranjeros de Hermosillo, equipo de su ciudad natal. Apasionada del beisbol, era admiradora de Benjamín "Cananea" Reyes, a quien yo detestaba porque dirigió a los Diablos Rojos del México a principios de los años 70, cuando siempre apaleaban a los Leones de Yucatán en la Liga de Verano. Después de platicar con Raquel más a fondo de la historia de vida de "Cananea" Reyes, debo reconocer que mi antipatía por él desapareció por completo.

Poco después de aquellos encuentros, Raquel presentó su tesis de licenciatura por la Facultad de Antropología local. Pasado un año, con motivo de una reunión de historia colonial en la ciudad de México, el colega Juan José Gracida Romo me comentó que Raquel recién había ingresado como investigadora del INAH en Sonora. Era notoria la satisfacción de Juan José pues, dijo, "Raquel tiene un buen trabajo sobre los yaquis en Yucatán". ${ }^{3}$ A partir de su ingreso al INAH, Raquel empezó a desplegarse con gran potencial académico e intelectual. Su caminar pausado era parte de la agudeza de sus dichos como historiadora. El dinamismo y originalidad de su actividad académica, entre otros atributos como líder familiar, dieron cuenta de que enfrente teníamos a una mujer brillante y lúcida.

Tiempo después compartimos espacio laboral y profesional con Raquel en el Centro INAH, algo que fue siempre ameno, provechoso y fructífero. Sus conocimientos entrecruzados de las historias de Sonora y Yucatán, dejaban siempre inevitable huella de cómo entender dos mundos regionales distintos y complejos, injustos y canallas con sus respectivos pueblos originarios. Ambos teníamos conocimiento de las oligarquías porfiristas regionales, ella de Sonora, yo de Yucatán. Raquel entendió como pocos la mentalidad y acciones criminales de los poderosos de Sonora y Yucatán contra la nación yaqui, con todo y que algunos los defendían por "su gran capacidad de trabajo". Sobre los momentos que compartimos con Raquel como colega comprometida con la investigación, defensa y protección del patrimonio histórico y antropológico, abundo en este texto ya que muestran la claridad y amplitud de su compromiso social como de su pensamiento.

\footnotetext{
${ }^{1}$ Una primera versión de este texto se presentó el 22 de noviembre del 2019 en El Palacio Cantón de la ciudad de Mérida bajo el título "Gracias Raquel...”, como parte del homenaje que en su memoria organizó el Centro INAH Yucatán.

${ }^{2}$ Hernán Menéndez falleció el 2 de enero del 2002, fue amigo y colega de Raquel Padilla.

${ }^{3}$ La tesis se convirtió en el libro Yucatán, fin del sueño Yaqui. El tráfico de los yaquis y el otro triunvirato (1995), Ed. Gobierno del Estado de Sonora, cuya temática principal fue la deportación de los yaquis a las haciendas henequeneras de Yucatán.
} 


\section{Entre Sonora y Yucatán}

Raquel llegó a estudiar la licenciatura en Historia a la Universidad Autónoma de Yucatán debido a, si recuerdo con certeza, la petición familiar para no recalar a la siempre intimidante capital de México, el ex DF. En Yucatán encontró su segunda patria. Todos la adoptamos como compañera, colega y sobre todo amiga, si no es que para muchas y muchos como hermana. Un segundo momento de contacto con ella fue precisamente cuando recaló de nuevo a Yucatán para estudiar la maestría en etnohistoria. Fuimos entonces vecinos de cubículo en la Sección de Historia. El investigador Enrique Montalvo, con quien también tuvo gran amistad, le cedió sin dudar parte de su espacio laboral. En ese momento Raquel ya descollaba como conocedora de la diáspora de la nación y etnia Yaqui, la pasión intelectual de su vida y, como ella declaraba: "Solo soy una vocera de los sueños y luchas yaquis". Hoy entendemos por que vocera, pero también parte esencial de la lucha contemporánea de uno de los pueblos prehispánicos de México más orgullosos y celosos de su identidad y defensa de su territorio e integridad originaria. $^{4}$

Para entonces Raquel ya se perfilaba como especialista del conocimiento del drama histórico vivido hasta la fecha por los pueblos originarios, en particular la nación yaqui, víctima una y otra vez de violencia, esquemas religiosos y leyes arbitrarias del poder político europeo colonial y luego del mexicano. ${ }^{5}$ Sed de dominio y control occidental del vasto territorio yaqui al sur de la sierra

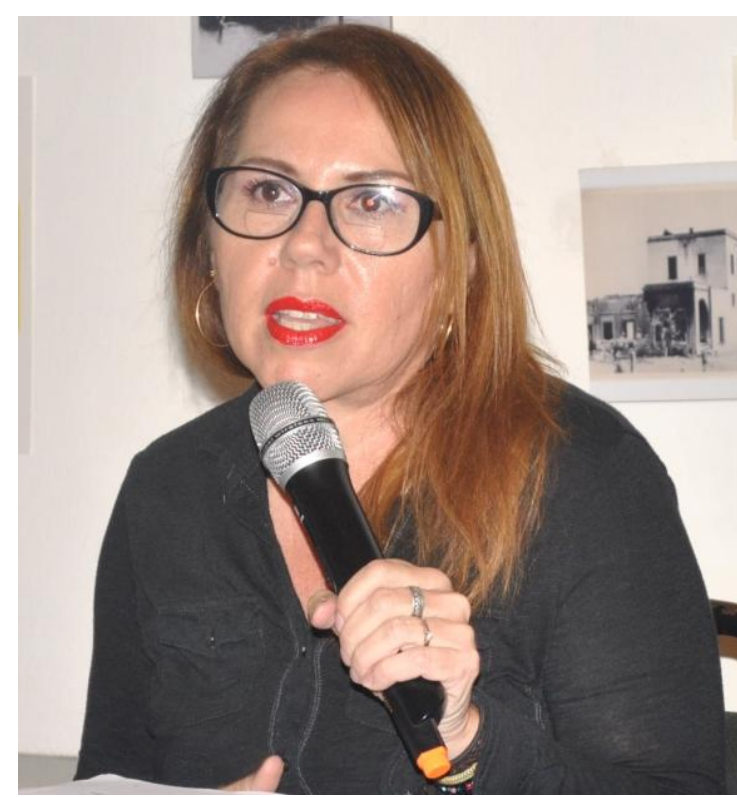

La Dra. Raquel Padilla Ramos en el Seminario de Historia y Antropología sobre ámbitos costerosos y marítimos. Museo Arqueológico de Mazatlán, INAH, Sinaloa.

de Bacatete son la constante en su lucha como nación. Un empeño tozudo de Raquel fue por tanto documentar, entender y difundir a detalle todo lo concerniente a la defensa de la etnia y nación prehispánica yaqui a la que se unió en cuerpo y mente, y transitó hasta el día de su muerte como aliada orgánica e incondicional. Por eso sobre el maltrato a los pueblos originarios compartimos y coincidimos, como también diferimos de forma respetuosa, en posturas críticas. No solo sobre la violencia histórica que les impuso el poder político colonial y oligárquico liberal de México, sino en temas relativos al papel del INAH, o quizá deba decir del rumbo del Estado mexicano bajo rectoría neoliberal, respecto a demandar una actitud más firme en favor de los derechos de los pueblos originarios.

\footnotetext{
${ }^{4}$ La temática del regreso de la nación Yaqui a Sonora la abordó Raquel en el libro Progreso y Libertad. Los Yaquis en la víspera de la repatriación (2006), Hermosillo, Ed. Programa Editorial de Sonora e Instituto Sonorense de Cultura. Con este texto Raquel dio seguimiento a la suerte de los Yaquis con el régimen de Francisco y Madero.

${ }^{5}$ Este aspecto lo trató Raquel en el libro Conflicto y armonía: etnias y poder civil, militar y religioso en Sonora (2009), México, INAH.
} 


\section{La tragedia del ABC y el Internado Cruz Gálvez}

Raquel también sobresalió como activista social en otros momentos, como cuando ocurrió la tragedia de la guardería ABC en Hermosillo, Sonora. Tuvimos una charla larga y cruda al respecto. Me reveló detalles espeluznantes. Comprendió a fondo el drama vivido por padres y madres de casi media centena de niños fallecidos el año 2009, a quienes apoyó sin reparo. No fue la primera ni la última vez que Raquel se involucró en una lucha contra la corrupción y la injusticia de grupos fácticos y del poder, recibiendo por ello amenazas diversas, por desde luego poderes cobardes y siniestros. Raquel, recuerdo, mantuvo ante esas intimidaciones, firmeza y templanza.

El año 2006, ante la amenaza y demagogia del gobierno estatal de Sonora de desalojar el Internado Coronel J. Cruz Gálvez, recibimos en la oficina sindical de los profesores del INAH, el llamado para participar de forma inmediata en su defensa. Desempeñaba el cargo de Secretario General de nuestra entonces delegación sindical de investigadores. La defensa del Internado no fue la lucha por defender un espacio nostálgico. Fue, como bien caracterizó Raquel, una doble lucha. Representaba la protección simultánea de un proyecto educativo popular y de un monumento histórico que marcó el antes y después de la educación en México, sonorense en especial. Fue edificado entre las miserias que legó el porfiriato y la esperanza que albergó la Revolución mexicana.

El primer objetivo fue frenar la avanzada más decidida del capital financiero local, a través de actos del gobierno estatal, que deseaba destinar para otros fines las tres hectáreas con que contaba (y aún conserva) el internado como convertir el edificio en despacho bancario o turístico. La agresión estatal buscaba dar en todo caso otro uso al conjunto arquitectónico construido por el pueblo sonorense entre 1917 y 1919 cuya misión fue proteger y educar a niños huérfanos de la Revolución. Explicaré de forma breve qué significado tiene este internado en cuya defensa se involucró Raquel con el conocimiento y la determinación que caracterizaba cada uno de sus pasos.

El IJCG fue inaugurado en 1919 para dar hogar e instrucción a niños huérfanos de la Revolución. Fue idea de Plutarco Elías Calles quien encomendó a su amigo el coronel J. Cruz Gálvez ejecutarla. En la construcción ayudó y participó el pueblo de Hermosillo y de otros puntos cercanos. El Cruz Gálvez es un espléndido edificio con arquitectura neo-clásica coronado con el triángulo del saber ilustrado, de cuyas aulas han egresado un gobernador (Samuel Ocaña) y no pocos personajes destacados en la política, la educación, la economía y la cultura sonorense. ${ }^{6}$ Su edificación se realizó cuando Hermosillo era pequeño. Al correr el siglo XX y XXI quedó rodeado de modernidad capitalista y de arquitectura funcionalista, influyendo en la valoración social y uso del edificio educativo. Las diez hectáreas con las que fue dotado de forma original, los subsecuentes gobiernos de la revolución mexicana las fueron engullendo en favor de intereses diversos. Devoraron hasta donde recuerdo el $70 \%$ de su extensión original. Y añejos terrenos ejidales que sirvieron para cultivos de los niños del Internado, se transformaron en calles, viviendas privadas, negocios y oficinas.

Un incendio propiciado a inicios del año 2006 en el pabellón dormitorio de niñas prendió la alarma de la sociedad, a nuestros compañeros del CINAH-Sonora y a egresados activos del internado como el mismo Dr. Ocaña. Nuestra tarea consistió entonces en desplegar una estrategia de defensa. Parte central de la articulación recayó en nuestros compañeros investigadores y arquitectos del CINAH-Sonora, con apoyo de compañeros de

${ }^{6}$ El Dr. Ocaña es autor de un breve pero riguroso y sustancial ensayo sobre la historia del Internado. 
Sinaloa. La sociedad sonorense identificada con el valor histórico, político y simbólico del internado fue el baluarte primordial de la disputa.

Raquel destacó en las acciones. Entrevistas conjuntas a medios diversos, publicaciones, entre otras actividades, se desplegaron a lo largo de varios días y semanas. Los grupos fácticos involucrados en las acciones criminales contra los niños y niñas del internado tuvieron que replegarse; se les obligó a asumir compromisos políticos y económicos con, en ese entonces, los notoriamente descuidados edificio y terreno, del centro educativo ejemplar de Sonora. Hasta la fecha recibe donaciones para más de 200 niños, casi todos procedentes de hogares marcados por carencias, desintegración de sus familias nucleares, como por razones más complejas ligadas a la migración por falta de oportunidades de trabajo.

Hoy día los videos sobre el Internado Cruz Gálvez no reflejan las condiciones de abandono en que se encontraba el edificio en 2006. El poder entendió el mensaje enviado desde la sociedad, con Raquel articulando parte relevante de la defensa. Por eso diez años después, en abril de 2017, regresamos a Hermosillo para participar en el centenario del inicio de su construcción a la vez que conmemorar la década de apoyar con firmeza la integridad y misión de ese centro educativo. Papel central de esta actividad la cumplió desde luego una vez más Raquel, como vínculo del movimiento social y de la memoria histórica regional, actuado en conjunto por sociedad sonorense y trabajadores del INAH.

\section{Una coincidencia más}

En el programa Tiempos, un momento con la historia del 6 de noviembre de 2015 Raquel participó con su tema de vida La deportación de los Yaquis a Yucatán, la diáspora que una y otra vez subrayó "más y de mayor forma marcó a toda la nación yaqui". ${ }^{7}$ Hubo un momento, destacó Raquel, que habían más yaquis en Yucatán que en su territorio de origen. Los yaquis llegaron a toda la península prácticamente como esclavos endeudados, en particular a las haciendas de henequén yucatecas. Todos tenían claro que debían regresar a su territorio. Muchos lo lograron, otros se integraron con todo y genes con sus hermanos mayas prehispánicos. Raquel nos enseñó a leer esos genes a través de fotos de rostros yaquis, de yaquis hablando maya. Después de ser presentada como autoridad en el tema, Raquel corrigió de forma amable y correcta a su entrevistador, el historiador Rangel Palafox, señalando que en el tema ella solo era una amanuense de la nación yaqui y que ellos son quienes saben, conocen y entienden mejor su propia dinámica histórica, política y cultural.

En el programa Raquel hizo una propuesta ante un hecho que, por entonces, se movía mucho en el país: la posible repatriación de los restos de Porfirio Díaz. Esta, era una situación derivada del hecho de que los descendientes de Díaz acumulaban deudas de pago de los derechos del cementerio parisino y se vence en 2020 el contrato de resguardo de los restos del dictador oaxaqueño. Con la tranquilidad que la caracterizaba, pero sin que sus palabras ocultaran su firmeza, Raquel propuso que antes de proceder a una acción de reivindicación del dictador Díaz (que parece ya no será), si no era más oportuno "im-

\footnotetext{
${ }^{7}$ Fui invitado por Raquel a presentar el año 2012 su libro Los irredentos parias. Los yaquis, Madero y Pino Suárez en las elecciones de Yucatán, 1911 (2011), México, INAH. En la obra Raquel abundó más en otras expresiones por las que pasó el pueblo en el exilio, los pactos a los que fueron sometidos por facciones políticas en pugna en Yucatán así como la mirada desconfiada que algunos sectores de la sociedad yucateca tenían de los yaquis que permanecían en la entidad.
} 
pulsar o crear una Comisión de la Verdad sobre los pueblos prehispánicos". Cuando menos argumentó para que el poder político mexicano "pida perdón a todos los pueblos prehispánicos, incluidos desde luego los yaquis".

Raquel mantuvo una postura muy avanzada, tal como se ve en el caso de su compromiso con el patrimonio histórico como en el reconocimiento de derechos ancestrales de los pueblos originarios. La revisión que he dado a sus obras, sus entrevistas, sus participaciones así como las opiniones que compartimos en reuniones diversas, me dejan claro que estábamos frente a una compañera que marcaba e indicaba como pocos el rumbo político y nivel de compromiso que debemos tomar ante los cambios que se avecinan. Ser voceros o amanuenses de los pueblos originarios, tal como ella vivió y sintió, implicaba adoptar una postura clara en favor de sus derechos históricos, vilipendiados cuando no cancelados a través de incomprensión, odio, despojo e incluso exterminio. Como ella documentó sobre los yaquis.

Fue una intelectual orgánica, diría Gramsci, con capacidad para entender y saber integrar pasado, presente y futuro con la lucha cotidiana y los derechos sociales y políticos de la población infantil huérfana o sin recursos; de paso, del patrimonio histórico y, en su caso particular, por la lucha y defensa del pueblo yaqui. Raquel era una historiadora militante de la cultura y del patrimonio. Su muerte nos impactó y nos hizo llorar a muchos. Su vida y obra nos debe dejar contentos pues es el ejemplo de un pensamiento y una actitud decidida por entender, luchar y respetar a los pueblos originarios.

Iván Franco

Instituto Nacional de Antropología e Historia - Centro Yucatán (México) DOI: https://doi.org/10.31057/2314.3908.v7.n2.27679 
